inviting prominent political scientists to annual meetings to offer research workshops and short courses or "state of the field" seminars and offering workshops on scrvice learning and civic education to $\mathrm{K}-12$ teachers.

As 1999 Goodnow Award winners Malcolm Jewell and Doris Graber noted, strong state associations are necessary for the health of the discipline. State associations are a public good that can offer many benefits to faculty, graduate students, undergraduates, and the broader public. To join a discussion of how to keep state associations fulfilling their important functions, subscribe to the APSA-State listserv by sending the following message to listserv $(a \mathrm{~h}-$ net.msu.edu: subscribe APSA-State yourname yourinstitution (ex: subscribe APSA-State John Doe State University). You can also send your questions, ideas, and suggestions to Sue Davis at sdavis(a apsanet.org.

\section{Sue Davis Joins APSA Staff}

APSA is pleased to announce that Sue Davis, a Ph.D. graduate of Emory University who specializes in comparative politics with a focus on the areas of the former Soviet Union, has joined the Association staff.

Dr. Davis came on board to be Director of International Programs and also has primary staff responsibility for the Association's Organized Sections, survey activities, and status committees.

She did her undergraduate work at the University of Minnesota and the University of Nevada, Las Vegas and received a master's degree from UNLV after writing a thesis on politics in the Baltic States under Gorbachev. She spent the past three years at Grand Valley State University in Grand Rapids, Michigan, and has also taught at Georgia Tech, Emory, Oglethorpe University, and UNLV.

Dr. Davis has published widely on topics as diverse as ethnicity in Kazakstan, partics in Ukraine and Poland, and trade unions in the former Soviet Union. She is currently preparing a manuscript based on her dissertation for publication with
Macmillan on trade unions in Russia and Ukraine and has just contracted with Harwood Academic Publishers to write a book tentatively titled The Russian Far East: The Last Frontier, which will be issued in the Postcommunist States and Nations series.

She currently serves as vice president of the Association for the Study of Nationalities and is an active member of Women in International Security, the Southern Political Science Association, the American Association for the Advancement of Slavic Studies, the International Political Science Association, and, of course, APSA. In addition, Dr. Davis is an adjunct professor at the U.S. Air Force Special Operations School, where she lectures on Ukraine, Belarus, the Caucasus, and ethnic conflict.

\section{8-99 Congressional Fellows Honored, 1999- 2000 Fellows Welcomed}

From the purist's point-of-view, the only "right" time to conclude a working experience with the Congress is when the final gavel adjourns the institution sine die. For a ten-month program, which has to merge diverse career needs of political scientists, journalists, government employees, international scholars, and health-policy professionals, the American Political Science Association's Congressional Fellowship Program compromise has traditionally been August 15-when the Fellows are treated to a reception in the Capitol.

As illustrated by the photo below, the annual event inevitably draws members of Congress for whom the Fellows worked this session such as Representatives Sherwood Bochlert (R-NY), Eva Clayton (D-NC), Rush Holt (D-NJ) and Senators Frank Lautenberg (D-NJ) and Richard Lugar (R-IN). Other welcome guests included two CFP alumni currently serving in Congress, Representatives Steve Horn (R-CA) and Bob Filner (D-CA); former journalist Fellows Craig Hines, Washington, DC bureau chief for the Houston Chronicle, and Larry Hojo, who came into the program from the $I n$ diana Gazette; and a host of political science alumni still in the DC area including Josef Braml, Charles Clapp, Chris Deering, Paul Herrnson, current chair of the Fellowship Alumni Committee Norm Ornstein, APSA Executive Director Cathy Rudder, Paul Runquist, Mark Sicgel, Jim Thurber, and Tom Wolanin.

The departure of the 1998-99 class of Congressional Fellows was followed shortly by the arrival of the

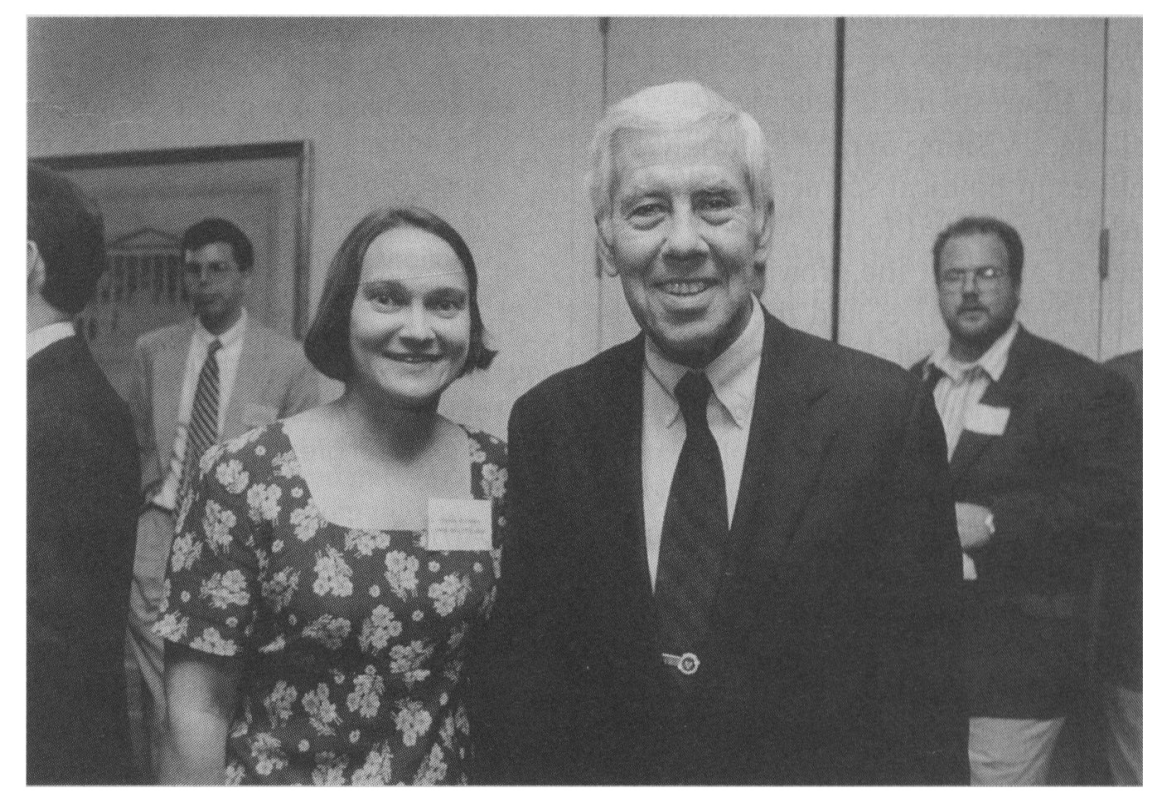

1998-99 Congressional Fellowship Year-End Reception. (R-L) Congressional Fellow David Leal, University at Buffalo-SUNY; Congressional Fellow Susan Rzemien U.S. Treasury Department; CFP Advisory Committee member Senator Richard Lugar (R-IN) in whose office Ms. Rzemien served as a Legislative Assistant; and William Koetzle, 1997-98 Congressional Fellow, legistative director to House Speaker Dennis Hastert (R-IN). 
1999-2000 class who began their four-week orientation in November. The political scientists among the group are indicative of the ever-widening range of the discipline and the relevance of the legislative process. In addition to the two Carl Albert Fellows from the University of Oklahoma (Leslie McCollum and Craig Williams), the group includes two doctoral graduates as APSA-MCI WorldCom Fellows from the University of Toronto (Chantal Blouin) and Northwestern University (James Snider) who will focus on both U.S. and international telecommunications policies, a University of California, San Diego graduate (Daniel Kaufman) who has specialized in Latin America and comparative politics, two German Marshall Fund Fellows and doctoral candidates from the University of Potsdam, Berlin (Michael Kolkmann) and Munich University (Simone Stemmler), and Johns Hopkins University SAIS graduate and Ford Foundation Fellow Mohamed Kamal who will return at the end of the program to assume a teaching position in U.S. politics and the legislative process at the newly-inaugurated American Studies Center at Cairo University.

Gearing the orientation and biweekly Wilson Seminar series to the increased diversity of Congressional Fellow interests has a become a challenge. Visiting Senior Fulbright Scholars in political science will continue to be invited to the Wilson series to augment the growing international perspective, and the orientation program will continue to draw heavily upon political science alumni in the D.C. area including

Stan Bach, 1972-73 Congressional Fellow and senior specialist at the Congressional Research Service

Walter Beach, former CFP director, 1998 Goodnow Award winner, and senior fellow at the Helen Dwight Reid Educational Foundation

Chris Deering, 1984-85 Congressional Fellow and professor of politi- cal science at George Washington University

Alton Frye, 1961-62 Congressional Fellow and vice president of the Council on Foreign Relations
Paul Herrnson, 1989-90 Congressional Fellow and professor at the University of Maryland

Frederick Holborn, professor at Johns Hopkins SAIS and director of

\section{JPSA Representatives Participate in 1999 Meeting}

As part of its continuing exchange with the Japanese Political Science Association, APSA hosted four JPSA members at the recent meeting in Atlanta. Hiroshi Hirano of Gakushuin University, Kuniaki Tanabe of Tokyo University, and Kengo Akiduki of Kyoto University each presented papers under the auspices of the exchange program. Additionally, Yoshiaki Kobayashi of Keio University, and JPSA liasion to APSA, attended the convention.

In early October, APSA members Terry Clark of the University of Chicago and Jong S. Jun of California State University, Hayward traveled to Tokyo at the invitation of the JPSA as APSA representatives to the Japanese Annual Meeting. Both scholars participated on a special panel that included scholars from the JPSA/European Consortium for Political Research exchange program.

Since 1990, the APSA and JPSA have exchanged delegations to their respective annual meetings, facilitating the exchange of research and methods and bridging the distance between communities.

\section{NEWS FROM IPSA}

\section{IPSA Names New Secretary General-Designate}

At its April meeting in Krakow, Poland, the International Political Science Association executive council appointed Guy Lachapelle of Concordia University as the new secretary general-designate. Lachapelle will become secretary general at the conclusion of current director John Coakley's term in 2000. All coordinating activities for IPSA will move to Concordia University in Montreal, Canada, for the duration of Lachapelle's three-year term.

Lachapelle is a professor in the political science department at Concordia, where he has served since 1984. In addition to teaching at Concordia, he is also coordinator of Quebec Government Relations at the Office of Government \& External Relations. Previously, he has served as president of the Société Québécoise de science politique (1996-97). He currently serves as co-chairperson Guy Lachapelle of the organizing committee of the XVIII IPSA

World Congress, to be held in Quebec City in 2000.

\section{Africa to Host XIX IPSA World Congress}

For the first time, an IPSA World Congress will be held on the African continent in 2003. At its April meeting, the IPSA executive council accepted a joint invitation from the African Association of Political Science and the South African Political Science Association. The meeting will take place in Durban, South Africa, June 30-July 5.

Be sure to follow all of the Association's international activities via APSANet, the American Political Science Association online at www.apsanet.org/about/international. 
the CFP foreign affairs seminar for more than two decades

Norman J. Ornstein, 1969-70 Congressional Fellow and American Enterprise Institute Resident Scholar

Bill Koetzle, 1997-98 Congressional Fellow and legislative director to House Speaker Dennis Hastert

George Kundanis, 1976-77 Congressional Fellow and senior assistant to House Democratic Leader Richard Gephardt

Paul Light, 1982-83 Congressional Fellow and vice president and director of governmental studies at The Brookings Institution

Thomas Mann, 1969-70 Congressional Fellow, former CFP director, APSA executive director, 1999 Goodnow Award winner, and senior scholar at The Brookings Institution

Jim Thurber, 1973-74 Congressional Fellow and professor and director of the center for Congressional and Presidential Studies at American University.

If there were ever a question as to how dependent the APSA Congressional Fellowship Program is on its alumni, the list of these "faculty" answers the question: a very great deal.

\section{APSA Welcomes New Section on Interdisciplinary Approaches to International History and Politics}

During their meeting on September 1, members of APSA's Council approved the establishment of an Organized Section on Interdisciplinary Approaches to International History and Politics.

Section organizers have set themselves the goals of promoting the study of international history and politics, encouraging interdisciplinary conversations between political scientists and historians, advancing the development, dissemination, integration, and application of qualitative and historiographical methodologies, and distributing research results derived from the application of such methodologies. The section's first president, Alexander George, has also expressed his hope that the section will provide an institutional focus for the recent resurgence in the qualitative study of international politics and serve as a permanent point of access for dialogue between international, diplomatic, economic, and military historians and political scientists who study international relations and foreign affairs.

The section welcomes all scholars and scholarship that intersect with its purposes, regardless of their preferred methodology or epistemology. Annual dues are $\$ 5$, and can be paid as part of the APSA membership renewal. Members wishing to join the section before they are asked to renew their APSA memberships should contact APSA at 202-4832512 or membership@apsanet.org.

More information regarding the goals and purposes of the section can be found on APSA's web site (www.apsanet.org/about/sections). Specific questions should be directed to Section Vice President Andrew Bennett (202-687-5800; bennetta@gunet.georgetown.edu) or Section Secretary-Treasurer Colin Elman (617-495-1035; colin-elman@harvard.edu).

\section{Section News}

Political Psychology

- At their 1999 business meeting, section officers honored Robert Lane by naming its annual book award for him. They also honored Margaret $\mathrm{M}$. Hermann by naming the section's graduate student scholarship award for her. The scholarship makes it possible for a student to attend the OSU-ISPP Summer Institute in Political Psychology. They also discussed plans to raise funds for endowing these awards and supporting others. In other business, section officers named Diana Mutz and Robert Jervis members of the 1999 book award committee.

- Political Psychology Division Chair Stanley Feldman, SUNY-Stony Brook, organized nine section panels for the Annual Meeting Program, which were well attended. Laura Stoker, University of California, Berkeley, will serve as division chair for the 2000 meeting.

- The newsletter of the section, The Political Psychologist, is now being coedited by Stanley Feldman, Leonie Huddy, and Milton Lodge at
SUNY-Stony Brook. From 1996 to 1998 , it was produced by the Center for the Study of Political Psychology at the University of Minne sota. The spring 1999 issue focused on political and social identity and featured contributions by Katherine Cramer, Marc Howard Ross, David O. Sears, P.J. Henry, and Marilynn Brewer. The next issue will include articles on issue framing.

\section{Organized Sections Distribute Awards at Annual Meeting}

At their respective meetings during APSA's 1999 Annual Meeting in Atlanta, Organized Sections presented over 50 awards recognizing dissertations, books, papers, and careers. Many of these section prizes are annual and nominations are sought at this time for next year's awards. For further information be sure to visit APSANet (www. apsanet.org/about/sections).

\section{Federalism and Intergovernmental Relations}

The Distinguished Scholar Award, recognizing distinguished scholarly contributions to the study of federalism and intergovernmental relations, was presented to Joseph Zimmerman, a member of the department of political science at University at Albany-SUNY. The Best Paper Award was conferred upon Troy Smith of Brigham Young University for his paper, "When States Lobby: Welfare Reform, 1993-1997." The Best Book Award, given for the best book on federalism and intergovernmental relations published at least 10 years ago that has made a lasting contribution to the study of federalism and intergovernmental relations, was presented to Vincent Ostrom of Indiana University for The Political Theory of the Compound Republic (Public Choice, 1971)

\section{Law and Courts}

Members of the Law and Courts section saw the American Judicature Society Award conferred upon Melinda Gann Hall of Michigan State University for her paper, 